\title{
Correlation Model of Delay in Project Management
}

\author{
Umar A. Altahtooh \\ Taibah University \\ E-mail: utahtooh@taibahu.edu.sa
}

Received: May 4, 2016

Accepted: July 14, 2016

Published: July 14, 2016

doi:10.5296/jmr.v8i3.9602

URL: http://dx.doi.org/10.5296/jmr.v8i3.9602

\begin{abstract}
Time errors are still a new concept in the field of project management, so there is a need to discover where they can happen throughout the project lifecycle. The previous research on this area is conceptual in nature and restricted to the definition and causes of time errors. This paper seeks to find the correlations between uncertainty and delay, between time errors and delay, and between uncertainty and time errors. It also seeks to find where exactly time errors can occur during the 47 project management processes identified in the PMBOK guide. Data were gathered using a survey of 40 project managers and analyzed using the statistical program SPSS. The findings show that there are relationships among the studied variables. Time errors can occur in any of the five groups of project management processes, with varying rates. The outcomes introduce a picture for main stakeholders in project management to avoid the occurrence of time errors as far as possible in project management processes.
\end{abstract}

Keywords: Project management, PMBOK, Saudi Arabia, Time error 


\section{Introduction}

Achieving projects on time and on budget is an important goal for stakeholders and organizations. Unfortunately, if a project is complex, it can run over time and budget because it has many decisions. Altahtooh (2016) shows that time errors lead to delay because of uncertainty in project management. As projects can have time errors, there is a requirement to know where these time errors can happen throughout the project lifecycle and to know what the relationship between time errors and uncertainty is. This study is empirical and exploratory in nature and is conducted through questionnaires. It aims to provide a view on the probability of occurrence of time errors by exploring these questions:

- Question 1: What are the correlations between uncertainty and delay, between time errors and delay, and between uncertainty and time errors?

- Question 2: Where can time errors occur throughout the 47 project management processes identified in the PMBOK guide?

To answer the explorative questions above, the researcher conducted a survey and analyzed the collected data using the software program the Statistical Package for Social Science (SPSS). The paper is divided into four sections. First, this study reviews the relevant literature relating to project management and uncertainty. Next, it describes the research hypotheses. After that, it discusses the method of research and presents the outcomes. Finally, the paper summarizes the implications of the findings for research and practice.

\section{Literature Review}

\subsection{Project Management}

This section aims to explore the concept of project management based on the PMBOK standard. A project is defined as "a temporary endeavor undertaken to create a unique product, service or result" (PMI, 2013, p. 3). Every project has a lifecycle, which means it has a start point and an end point. In addition, a project has to have a defined aim to make a product or to introduce a service. Projects vary in urgency, importance, duration, cost, scope, complexity, and required skills and resources. However, Soldano and Krueger (1994) show that a project has the following specific characteristics:

- $\quad$ precise scope with specific goals

- $\quad$ interrelated tasks with definite durations

- $\quad$ specific start and end dates

- defined resource needs and limitations

Each sector has different types of projects; for example, residential and non-residential projects are types of projects in the construction sector. In addition, software and hardware projects are types of projects in the IT industry. All projects should be led by project managers in order to achieve success. Researchers have covered project success factors deeply for different types of projects. However, many projects continue to fail because of 


\section{Macrothink}

various causes. The outcomes of a project can be classified into three types:

- $\quad$ successful

- $\quad$ challenged (grey project)

- failed

The failure rate of projects is high. For example, $75 \%$ of all IT projects fail (Harrington et al., 2000). In addition, delay is a problem in the construction sector (Shi et al., 2001). In order to mitigate failure and delay, key organizations have been founded to provide many services in the field of project management. The famous project management organizations are as follows:

1. Project Management Institute

2. Association for Project Management

3. International Project Management Association

All the above organizations direct their service packages (training, research, consulting, etc.) to their members but mainly focus on project managers. According to the Project Management Institute (PMI, 2013, p. 17), the project manager is "the person assigned by the performing organization to lead the team that is responsible for achieving the project objectives". In addition, the link between implementing the strategy and directing the team is the project manager (PMI, 2013). Project managers should have the necessary expertise and skills. The characteristics of project managers are shown in Table 1 (Anderson, 1992): 
Table 1. Project Managers' Profiles

\begin{tabular}{|l|l|l|l|}
\hline Human skills & Leadership skills & $\begin{array}{l}\text { Technical } \\
\text { experience }\end{array}$ & $\begin{array}{l}\text { Administrative } \\
\text { experience }\end{array}$ \\
\hline $\begin{array}{l}\text { motivating } \\
\text { team }\end{array}$ & leader and director & $\begin{array}{l}\text { recognize } \\
\text { technology }\end{array}$ & planning \\
\hline team building & commitment & $\begin{array}{l}\text { understanding of } \\
\text { engineering } \\
\text { process }\end{array}$ & managerial skills \\
\hline $\begin{array}{l}\text { integrating } \\
\text { project team }\end{array}$ & problem solving & $\begin{array}{l}\text { applications and } \\
\text { techniques }\end{array}$ & $\begin{array}{l}\text { estimating techniques, } \\
\text { cost, scheduling and } \\
\text { quality }\end{array}$ \\
\hline communication & $\begin{array}{l}\text { balance technical, } \\
\text { financial and } \\
\text { human factors }\end{array}$ & $\begin{array}{l}\text { technology } \\
\text { development }\end{array}$ & process development \\
\hline $\begin{array}{l}\text { conflict } \\
\text { management }\end{array}$ & decision making & $\begin{array}{l}\text { conflict } \\
\text { management }\end{array}$ & \\
\hline
\end{tabular}

Regarding project management, it is a combination of two main knowledge areas: art and science. Project management is "the application of knowledge, skills, tools and techniques to project activities to meet the project requirements" (PMI, 2013, p 47). The PMBOK guide was developed by the Project Management Institute as a collection of 47 processes and ten knowledge areas in the fifth edition. In addition, this guide is accepted by many organizations around the world as a reference for best practices for project management. The 47 project management processes are organized into five groups:

1. Initiating process group

2. Planning process group

3. Executing process group

4. Monitoring and controlling process group

5. Closing process group

The ten knowledge areas are shown as follows: 1) project integration management; 2) project scope management; 3) project time management; 4) project cost management; 5) project quality management; 6) project human resource management; 7) project communication management; 8) project risk management; 9) project procurement management; and 10) project stakeholder management. Thus, the structure of the PMBOK guide defines the 
process group and the knowledge area, and each process includes the purpose, inputs, tools and techniques, and outputs. According to Wateridge (1997), it is not easy to define the outcomes of a project (successful, failed or challenged). The reason is that these terms are debatable. Altahtooh and Emsley (2015) developed a new model (the project outcome model - POM) to categorize all the possible outcomes for any project (see Figure 1).

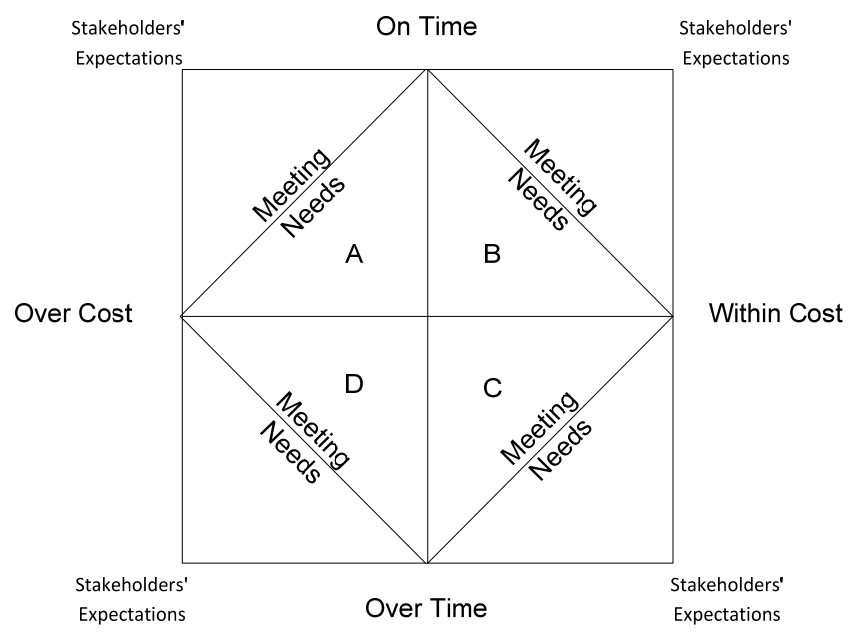

Figure 1. Project Outcome Model (Altahtooh and Emsley, 2015)

It is observable from Figure 1 that any project has a $50 \%$ chance of being challenged (grey project), a $25 \%$ chance of failing and a $25 \%$ chance of being successful. The real problem for many projects lies with grey outcomes, although most of these projects work effectively. Thus, Altahtooh and Emsley (2014) have suggested a way to deal specifically with all kinds of challenged projects (grey outcomes) by developing time error project correction (TEPC). This inconstant coefficient factor definitely differs from project to project.

\subsection{Project Uncertainty}

According to Rowe (1977), the term "uncertainty" means the absence of information. Hence, a lack of data or information throughout project management processes leads to project uncertainty. Furthermore, some project management processes use estimation tools to achieve accurate time and cost assessments. These estimations or expectations may lead to project uncertainty, which is an unknown negative or positive case (Altahtooh and Emsley, 2015). In the literature, there is a link between uncertainty and risk. Hertz and Thomas (1984) show that uncertainty and the results of uncertainty refer to risk. Olsson (2006) shows that uncertainty means both risk and opportunity. However, risk refers to threat and opportunity. According to PMI (2013, p. 310), risk is "an uncertain event or condition that, if it occurs, has an effect on at least one project objective". Regarding the difference between risk and uncertainty, Olsson (2006, p.122) points out that "Risk involves situations where the probability of outcome is known. Uncertainty is when the probability of outcome is unknown". 


\section{Research Model and Hypotheses}

According to Mayer (1989), a research model includes diagrams and words that help researchers to achieve the aim of the study. In terms of attaining the research objectives, the research model is simply a guide in gathering and analyzing data. According to Altahtooh (2016), time errors lead to delay and are an outcome of uncertainty (see Figure 2).

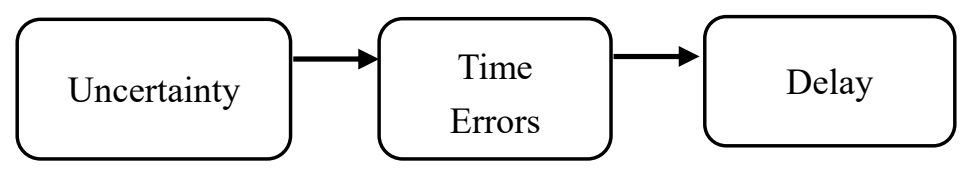

Figure 2. Nature of Time Errors (Adapted from: Altahtooh, 2016)

This paper shows the relationships between uncertainty and delay, between time errors and delay, and between uncertainty and time errors in the context of project management. The research model for this paper is shown in Figure 3.

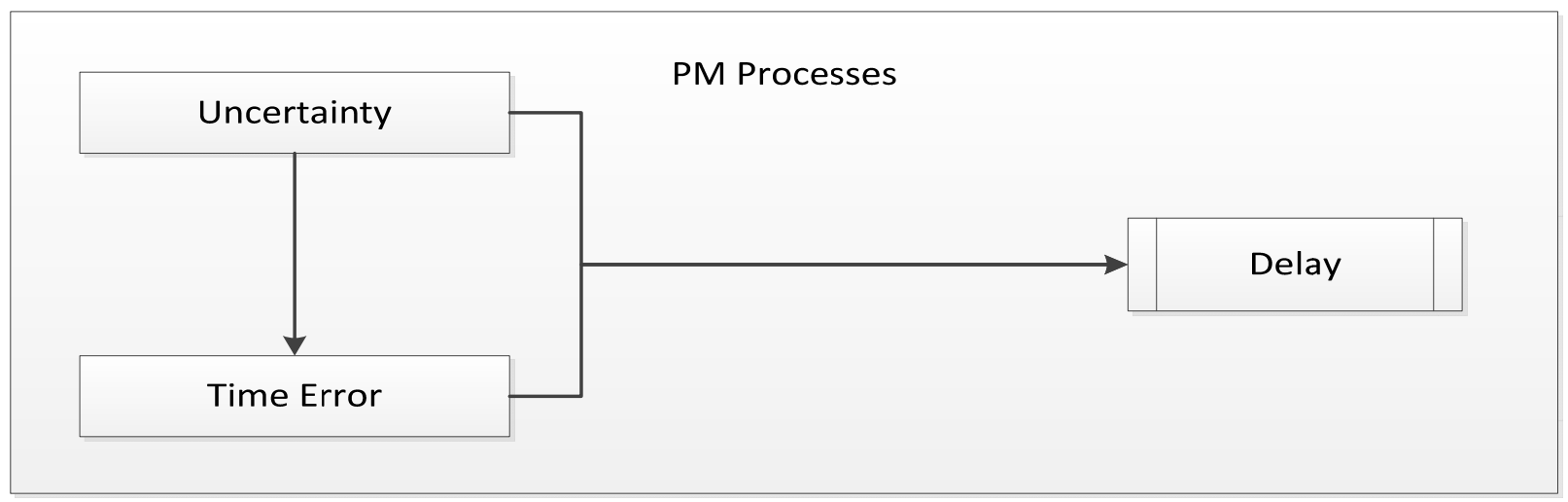

Figure 3. Research Model

The model was established based on the literature review and the PMBOK guide. It includes the following elements:

- $\quad$ Time errors

- Uncertainty

- Delay

As yet, no study has shown the aforementioned relationships. Thus, there was a need to test hypotheses. The research model helped to formulate three hypotheses:

H.1: There is a correlation between uncertainty and delay for project management processes.

H.2: There is correlation between time errors and delay for project management processes.

H.3: There is correlation between uncertainty and time errors for project management processes.

\section{Methodology}

Data were collected through a survey questionnaire for this paper. The questionnaire was 
designed based on the PMBOK guide and previous studies on time errors. The study employed a purposive sampling technique in selecting two main industrial cities (Yanbu and Jubail) in Saudi Arabia to collect data. The sample frame was restricted to project managers working in Saudi Arabia as follows: 30 in Yanbu and 30 in Jubail. Thus, questionnaires were sent to 60 project managers at the beginning of January 2016. The size of the sample was small because the study focused on a professional group. By the end of February 2016, questionnaires had been returned by 40 of the 60 project managers in the sample, with a response rate of $66.7 \%$. The completed questionnaires (17 from Yanbu and 23 from Jubail) were coded and analyzed using SPSS.

All items in the questionnaire used a five-point Likert scale, where 1 meant "strongly disagree" and 5 meant "strongly agree". The data gathered via the survey questionnaire were analyzed using descriptive statistics, while Pearson's correlation coefficient was used to test the hypotheses and determine the relationships among the variables. The aim of Pearson's correlation coefficient ( $r$ ) is to measure the strength of the association between two variables.

\section{Data Analysis and Results}

\subsection{Descriptive Statistics}

This section shows the descriptive statistics for the demographic information and the other independent variables considered in this paper. Table 2 introduces the frequency and percentage distribution of the respondents according to each demographic type. As shown in Table 2, the sample consisted of 40 male project managers (100\%) and no female project managers $(0 \%)$. Thus, there was a project management gender gap in Yanbu and Jubail. 


\section{Macrothink}

Table 2. Demographic Information of PMs

\begin{tabular}{cccc}
\hline & & Frequency & Percentage \\
\hline Gender & Male & 40 & 100.0 \\
Female & 0 & 0.0 \\
Total & 40 & 100.0 \\
Age $\quad<30$ & 3 & 7.5 \\
& & & \\
$30-35$ & 12 & 30.0 \\
$36-40$ & 15 & 37.5 \\
$41-45$ & 7 & 17.5 \\
$>45$ & 3 & 7.5 \\
Total & 40 & 100.0 \\
Level of Education & & \\
Below Bachelor's & 0 & 0.0 \\
Bachelor's & 31 & 77.5 \\
Higher Diploma & 2 & 5.0 \\
Master's & 7 & 17.5 \\
PhD & 0 & 0.0 \\
Total & 40 & 100.0 \\
\hline
\end{tabular}

Regarding age, the majority of the respondents were above 30 years old, wherein 12 participants were between 30 and 35 years old (30.0\%), 15 participants were between 36 and 40 years old (37.5\%), seven participants were between 41 and 45 years old (17.5\%) and three participants were above 45 years of age (7.5\%). In terms of educational level, $77.5 \%(\mathrm{n}=31)$ of the participants had completed a graduate degree and $22.5 \%(\mathrm{n}=9)$ had completed a postgraduate degree. Table 3 shows the professional information of the participants. Regarding industry area, six respondents $(15.0 \%)$ were from the construction industry, seven respondents $(17.5 \%)$ were from the manufacturing industry, 23 respondents $(57.5 \%)$ were from the petrochemical industries, one respondent $(2.5 \%)$ was from the IT industry and three respondents $(7.5 \%)$ were from other industries, such as consulting and engineering. The majority of the respondents had been participating in project management for 3-7 years (42.5\%), nine respondents $(22.5 \%)$ had been participating in project management for less than three years and eight respondents $(20.0 \%)$ had been participating in project management for $8-11$ years. Of the 40 participants, $14(35.0 \%)$ had a professional project management certification. 
Table 3. PMs' Professional Information

\begin{tabular}{ccc}
\hline & Frequency & Percentage \\
\hline Industry Area & & \\
Construction & 6 & 15.0 \\
Manufacturing & 7 & 17.5 \\
Petrochemical & 23 & 57.5 \\
IT & 1 & 2.5 \\
Other & 3 & 7.5 \\
Total & 40 & 100.0
\end{tabular}

Years of participation in PM

\begin{tabular}{cccc} 
Valid & $<3$ & 9 & 22.5 \\
& $3-7$ & 17 & 42.5 \\
& $8-11$ & 8 & 20.0 \\
& $12-15$ & 5 & 12.5 \\
& $>15$ & 1 & 2.5 \\
\multirow{2}{*}{ Valid } & Total & 40 & 100.0 \\
& Holding PM certification & \\
& Yes & 14 & 35.0 \\
& No & 26 & 65.0 \\
\cline { 2 - 4 } & Total & 40 & 100.0 \\
\hline
\end{tabular}

\subsection{Research Question 1}

In line with the research model, delay was used as a dependent variable for uncertainty and time errors, while time errors were used as a dependent variable for uncertainty. Table 4 shows interpretations of the dependent and independent variables studied in this study based on the PMBOK guide. The term "time errors" does not exist in the guide because it is a new one, and it still needs more research in the area of project management. According to Altahtooh (2016), a time error is "the difference between the actual project duration and the authorized project duration" (p. 59). 


\section{Macrothink}

Table 4. Interpretations of Dependent and Independent Variables

\begin{tabular}{|l|l|c|}
\hline Variable & Interpretation & Variable Types \\
\hline Delay & $\begin{array}{l}\text { "Project schedule delays can be so severe } \\
\text { that development of a new target schedule } \\
\text { with forecasted start and finish dates is } \\
\text { needed to provide realistic data for } \\
\text { directing the work" (PMI, 2013, p. 191) }\end{array}$ & $\bullet$ Dependent \\
\hline $\begin{array}{l}\text { Time } \\
\text { Errors }\end{array}$ & None & $\bullet$ Independent \\
\hline Uncertainty & $\begin{array}{l}\text { "Should be evaluated as potential causes } \\
\text { of project risk" (PMI, 2013, p. 322) }\end{array}$ & $\bullet$ Independent \\
\hline
\end{tabular}

The researcher used Pearson's correlation coefficient to test the three hypotheses related to research question 1 , as follows:

H1: There is a correlation between uncertainty and delay for project management processes.

Table 5 shows the frequency distribution of Likert scale agreement for the relationship between uncertainty and delay in the context of project management processes. The cumulative percentage for agree and strongly agree is $75 \%$.

Table 5. Relationship between Uncertainty and Delay

\begin{tabular}{|c|c|c|c|c|}
\hline & & Frequency & Percentage & \begin{tabular}{|l|} 
Cumulative \\
Percentage
\end{tabular} \\
\hline \multirow[t]{6}{*}{ Valid } & Strongly Disagree & 2 & 5.0 & 5.0 \\
\hline & Disagree & 3 & 7.5 & 12.5 \\
\hline & Neutral & 5 & 12.5 & 25.0 \\
\hline & Agree & 14 & 35.0 & 60.0 \\
\hline & Strongly Agree & 16 & 40.0 & 100.0 \\
\hline & Total & 40 & 100.0 & \\
\hline
\end{tabular}

Table 6 shows the Pearson's correlation of .824 between uncertainty and delay. The hypothesis is accepted at the $1 \%$ level. Thus, there is a positive correlation between uncertainty and delay for project management processes. 
Table 6. Correlation between Uncertainty and Delay

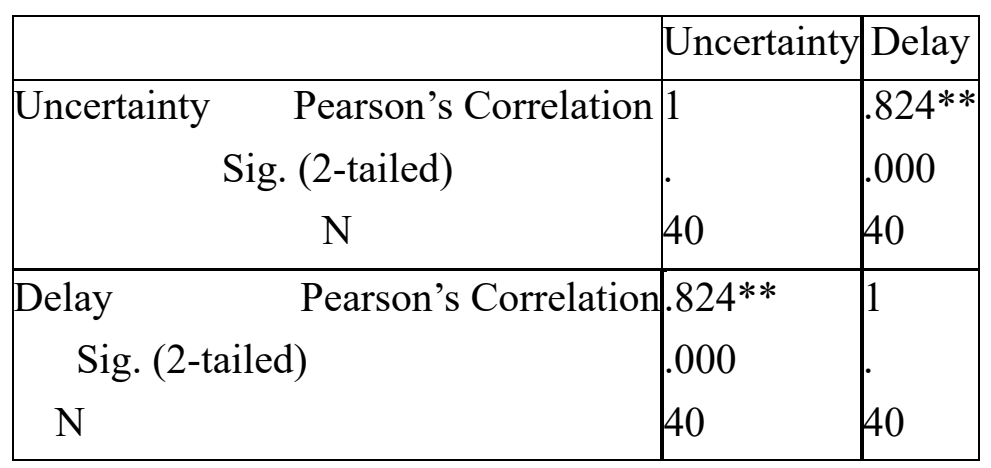

**. Correlation is significant at the 0.01 level (2-tailed).

H2: There is a correlation between time errors and delay for project management processes.

Table 7 shows the frequency distribution of Likert scale agreement for the relationship between time errors and delay in the context of project management processes. The cumulative percentage for agree and strongly agree is $87.5 \%$.

Table 7. Relationship between Time Errors and Delay

\begin{tabular}{|c|c|c|c|c|}
\hline & & Frequency & Percentage & $\begin{array}{l}\text { Cumulative } \\
\text { Percentage }\end{array}$ \\
\hline \multirow[t]{6}{*}{ Valid } & Strongly Disagree & 1 & 2.5 & 2.5 \\
\hline & Disagree & 2 & 5.0 & 7.5 \\
\hline & Neutral & 2 & 5.0 & 12.5 \\
\hline & Agree & 16 & 40.0 & 52.5 \\
\hline & Strongly Agree & 19 & 47.5 & 100.0 \\
\hline & Total & 40 & 100.0 & \\
\hline
\end{tabular}

Table 8 shows the Pearson's correlation of .868 between time errors and delay. The hypothesis is accepted at the $1 \%$ level. Thus, there is a positive correlation between time errors and delay for project management processes. 
Table 8. Correlation between Time Errors and Delay

\begin{tabular}{|l|l|l|}
\hline & Time Errors & Delay \\
\hline Time Error Pearson's Correlation & 1 & $.868^{* *}$ \\
Sig. (2-tailed) &. & .000 \\
$\mathrm{~N}$ & 40 & 40 \\
\hline Delay Pearson's Correlation & $.868^{* *}$ & 1 \\
Sig. (2-tailed) & .000 &. \\
$\mathrm{~N}$ & 40 & 40 \\
\hline
\end{tabular}

**. Correlation is significant at the 0.01 level (2-tailed).

H3: There is a correlation between uncertainty and time errors for project management processes.

Table 9 shows the frequency distribution of Likert scale agreement for the relationship between uncertainty and time errors in the context of project management processes. The cumulative percentage for agree and strongly agree is $92.5 \%$.

Table 9. Relationship between Uncertainty and Time Errors

\begin{tabular}{|ll|r|r|r|}
\hline & Frequency & Percentage & $\begin{array}{l}\text { Cumulative } \\
\text { Percentage }\end{array}$ \\
\hline Valid & Strongly Disagree & 1 & 2.5 & 2.5 \\
& 1 & 2.5 & 5.0 \\
Disagree & 1 & 2.5 & 7.5 \\
Neutral & 17 & 42.5 & 50.0 \\
Agree & 20 & 50.0 & 100.0 \\
Strongly Agree & 40 & 100.0 & \\
Total & & \\
\hline
\end{tabular}

Table 10 shows the Pearson's correlation of .888 between uncertainty and time errors. The hypothesis is accepted at the $1 \%$ level. Thus, there is a positive correlation between uncertainty and time errors for project management processes. 
Table 10. Correlation between Uncertainty and Time Errors

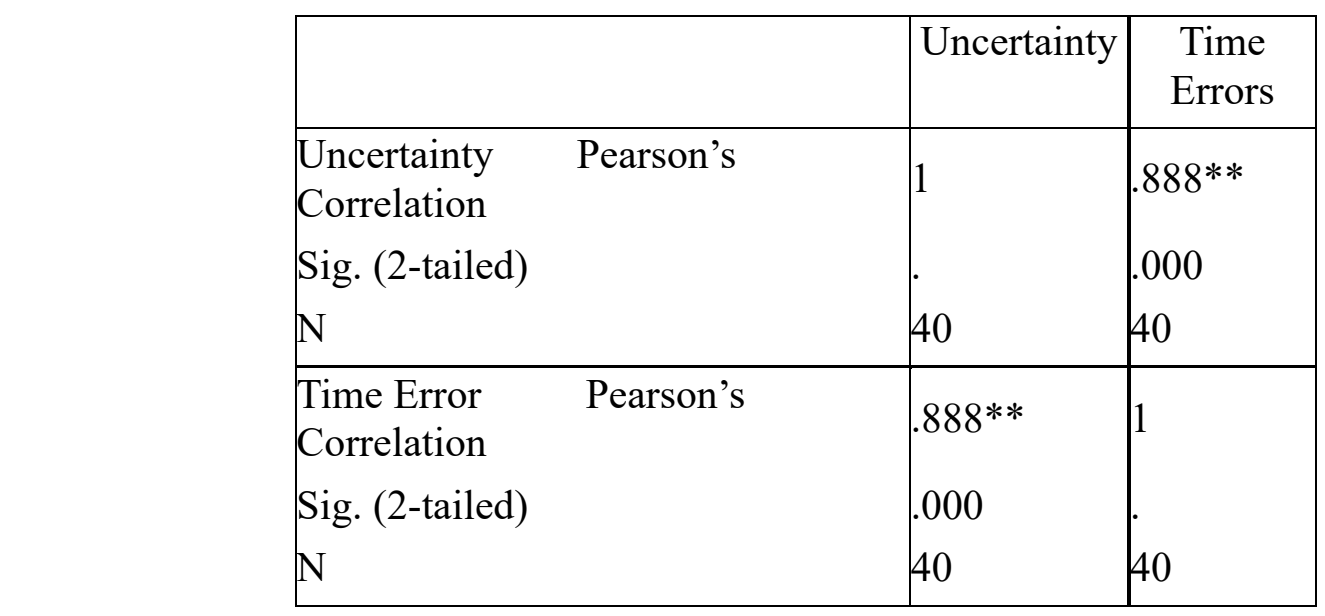

**. Correlation is significant at the 0.01 level (2-tailed).

\subsection{Research Question 2}

The objective of this question was to discover where time errors can occur in the 47 project management processes identified in the PMBOK guide. In order to find the occurrence of time errors in project management processes, the researcher asked the participants to pick one option from a three-point scale to indicate whether a time error could occur at that point: $1=$ high, $2=$ mid and $3=$ low. Table 11 shows the following information:

- 47 project management processes

- 9 knowledge areas

- 5 project management process groups

- the occurrence frequency of time errors for each process

According to Table 11, time errors had a high occurrence frequency in 11 project management processes. For instance, the frequency of time error occurrence in the process of "Perform Integrated Change Control" was ranked as follows: $80 \%$ (high) and 20\% (mid). Regarding the process of "Control Schedule", the frequency was as follows: $77.5 \%$ (high) and $22.5 \%$ (mid). The frequency of the process of "Control Costs" was categorized as follows: 75\% (high), 20\% (mid) and 5\% (low). 
Table 11. Occurrence Frequency of Time Errors for 47 Project Management Processes

\begin{tabular}{|c|c|c|c|c|c|c|}
\hline \multirow[t]{2}{*}{ No. } & \multirow[t]{2}{*}{ Process } & \multirow[t]{2}{*}{$\begin{array}{l}\text { Knowledge } \\
\text { Area }\end{array}$} & \multirow[t]{2}{*}{ Group } & \multicolumn{3}{|c|}{$\begin{array}{l}\text { Time Error } \\
\text { Chance }\end{array}$} \\
\hline & & & & Low & Mid & High \\
\hline 1 & 4.1 Develop a Charter & Integration & Initiating & 36 & 4 & 0 \\
\hline 2 & $\begin{array}{l}\text { 4.2 Develop Project Management } \\
\text { Plan }\end{array}$ & Integration & Planning & 33 & 5 & 2 \\
\hline 3 & $\begin{array}{l}4.3 \text { Direct and Manage Project } \\
\text { Work }\end{array}$ & Integration & Executing & 22 & 10 & 8 \\
\hline 4 & $\begin{array}{l}\text { 4.4 Monitor and Control Project } \\
\text { Work }\end{array}$ & Integration & $\begin{array}{l}\text { Monitor } \\
\text { and } \\
\text { Control }\end{array}$ & 7 & 9 & 24 \\
\hline 5 & $\begin{array}{l}\text { 4.5 Perform Integrated Change } \\
\text { Control }\end{array}$ & Integration & $\begin{array}{l}\text { Monitor } \\
\text { and } \\
\text { Control }\end{array}$ & 0 & 8 & 32 \\
\hline 6 & 4.6 Close Project or Phase & Integration & Closing & 10 & 24 & 6 \\
\hline 7 & 5.1 Plan Scope Management & Scope & Planning & 21 & 14 & 5 \\
\hline 8 & 5.2 Collect Requirements & Scope & Planning & 13 & 20 & 7 \\
\hline 9 & 5.3 Define Scope & Scope & Planning & 28 & 9 & 3 \\
\hline 10 & 5.4 Create WBS & Scope & Planning & 27 & 10 & 3 \\
\hline 11 & 5.5 Validate Scope & Scope & $\begin{array}{l}\text { Monitor } \\
\text { and } \\
\text { Control }\end{array}$ & 6 & 11 & 23 \\
\hline 12 & 5.6 Control Scope & Scope & $\begin{array}{l}\text { Monitor } \\
\text { and } \\
\text { Control }\end{array}$ & 5 & 8 & 27 \\
\hline 13 & 6.1 Plan Schedule Management & Time & Planning & 12 & 23 & 5 \\
\hline 14 & 6.2 Define Activities & Time & Planning & 10 & 22 & 8 \\
\hline 15 & 6.3 Sequence Activities & Time & Planning & 14 & 19 & 7 \\
\hline 16 & 6.4 Estimate Activity Resources & Time & Planning & 3 & 26 & 11 \\
\hline 17 & 6.5 Estimate Activity Duration & Time & Planning & 2 & 29 & 9 \\
\hline 18 & 6.6 Develop Schedule & Time & Planning & 11 & 21 & 8 \\
\hline 19 & 6.7 Control Schedule & Time & $\begin{array}{l}\text { Monitor } \\
\text { and } \\
\text { Control }\end{array}$ & 0 & 9 & 31 \\
\hline 20 & 7.1 Plan Cost Management & Cost & Planning & 11 & 23 & 6 \\
\hline 21 & 7.2 Estimate Costs & Cost & Planning & 4 & 27 & 9 \\
\hline 22 & 7.3 Determine Budget & Cost & Planning & 18 & 14 & 8 \\
\hline 23 & 7.4 Control Costs & Cost & $\begin{array}{l}\text { Monitor } \\
\text { and } \\
\text { Control }\end{array}$ & 2 & 8 & 30 \\
\hline 24 & 8.1 Plan Quality Management & Quality & Planning & 21 & 15 & 4 \\
\hline
\end{tabular}




\begin{tabular}{|c|c|c|c|c|c|c|}
\hline 25 & 8.2 Perform Quality Assurance & Quality & Executing & 18 & 11 & 11 \\
\hline 26 & 8.3 Control Quality & Quality & $\begin{array}{l}\text { Monitor } \\
\text { and } \\
\text { Control }\end{array}$ & 3 & 13 & 24 \\
\hline 27 & 9.1 Plan HR Management & HR & Planning & 17 & 18 & 5 \\
\hline 28 & 9.2 Acquire Project Team & HR & Executing & 20 & 8 & 12 \\
\hline 29 & 9.3 Develop Project Team & HR & Executing & 24 & 9 & 7 \\
\hline 30 & 9.4 Manage Project Team & HR & Executing & 16 & 12 & 12 \\
\hline 31 & $\begin{array}{l}\text { 10.1 Plan Communications } \\
\text { Management }\end{array}$ & Communication & Planning & 19 & 16 & 5 \\
\hline 32 & 10.2 Manage Communications & Communication & Executing & 17 & 13 & 10 \\
\hline 33 & 10.3 Control Communications & Communication & $\begin{array}{l}\text { Monitor } \\
\text { and } \\
\text { Control }\end{array}$ & 3 & 8 & 29 \\
\hline 34 & 11.1 Plan Risk Management & Risk & Planning & 13 & 20 & 7 \\
\hline 35 & 11.2 Identify Risks & Risk & Planning & 12 & 15 & 13 \\
\hline 36 & $\begin{array}{l}\text { 11.3 Perform Qualitative Risk } \\
\text { Analysis }\end{array}$ & Risk & Planning & 6 & 24 & 10 \\
\hline 37 & $\begin{array}{l}\text { 11.4 Perform Quantitative Risk } \\
\text { Analysis }\end{array}$ & Risk & Planning & 7 & 25 & 8 \\
\hline 38 & 11.5 Plan Risk Responses & Risk & Planning & 14 & 22 & 4 \\
\hline 39 & 11.6 Control Risks & Risk & $\begin{array}{l}\text { Monitor } \\
\text { and } \\
\text { Control }\end{array}$ & 4 & 11 & 25 \\
\hline 40 & $\begin{array}{l}\text { 12.1 Plan Procurement } \\
\text { Management }\end{array}$ & Procure & Planning & 21 & 13 & 6 \\
\hline 41 & 12.2 Conduct Procurement & Procure & Executing & 22 & 11 & 7 \\
\hline 42 & 12.3 Control Procurement & Procure & $\begin{array}{l}\text { Monitor } \\
\text { and } \\
\text { Control }\end{array}$ & 9 & 12 & 19 \\
\hline 43 & 12.4 Close Procurement & Procure & Closing & 21 & 16 & 3 \\
\hline 44 & 13.1 Identify Stakeholders & Stakeholders & Initiating & 30 & 7 & 3 \\
\hline 45 & 13.2 Plan Stakeholder Management & Stakeholders & Planning & 24 & 12 & 4 \\
\hline 46 & $\begin{array}{l}\text { 13.3 Manage Stakeholder } \\
\text { Engagement }\end{array}$ & Stakeholders & Executing & 19 & 15 & 6 \\
\hline 47 & $\begin{array}{l}\text { 13.4 Control Stakeholder } \\
\text { Engagement }\end{array}$ & Stakeholders & $\begin{array}{l}\text { Monitor } \\
\text { and } \\
\text { Control }\end{array}$ & 2 & 9 & 29 \\
\hline
\end{tabular}

The following table shows the frequency of time error occurrence for five project management process groups. 


\section{MInstitute Macrothink}

Table 12. Occurrence Frequency of Time Errors for Five Project Management Process Groups

\begin{tabular}{|l|c|c|c|c|c|}
\hline \multirow{2}{*}{ Group } & Number & \multicolumn{3}{|c|}{ Time Error Chance } & \multirow{2}{*}{ Total } \\
\cline { 3 - 5 } & Process & Low & Mid & High & \\
\hline Initiating & 2 & 66 & 11 & 3 & 80 \\
\hline Planning & 24 & 361 & 442 & $\mathbf{1 5 7}$ & 960 \\
\hline Executing & 8 & 158 & 89 & $\mathbf{7 3}$ & 320 \\
\hline Monitoring and Controlling & 11 & 41 & 106 & $\mathbf{2 9 3}$ & 440 \\
\hline Closing & 2 & 31 & 40 & 9 & 80 \\
\hline Total & 47 & 657 & 688 & 535 & $\mathbf{1 8 8 0}$ \\
\hline
\end{tabular}

According to Table 12, the Monitoring and Controlling Process Group had the highest time error occurrence frequency by $15.6 \%$ for 11 processes. The Planning Process Group was second by $8.4 \%$ for 24 processes, followed by the Executing Process Group by $3.9 \%$ for eight processes. For the mid time error occurrence frequency, the Planning Process Group came first by $23.5 \%$ and the Monitoring and Controlling Process Group was second by 5.6\%, followed by the Executing Process Group by 4.7\%. For the low time error occurrence frequency, the Planning Process Group was first by $19.2 \%$ and the Executing Process Group came second by $8.4 \%$, followed by the Initiating Process Group by $3.5 \%$ for two processes.

\section{Discussion}

Two main contributions were derived from the results. First, this is the first paper to examine the correlations between: i) uncertainty and delay, ii) time errors and delay, and iii) uncertainty and time error. According to Pallant (2010), Pearson's correlation is calculated to find the relationship between two variables. Mertler and Vannatta (2005) show that a Pearson's correlation between 0.00 and 0.30 means a weak relationship between two variables, between 0.31 and 0.70 means a moderate relationship and between 0.71 and 1.00 means a strong relationship. According to the results, there is a strong relationship between uncertainty and delay $(\mathrm{r}=0.824, \mathrm{p}<0.01)$. It is a positive relationship that shows that delay is associated with the increase of uncertainty. Furthermore, this study supports that there is a strong relationship between time errors and delay $(\mathrm{r}=0.868, \mathrm{p}<0.01)$. This means that delay is also related to an increase in time errors. This study finds that there is a strong relationship between uncertainty and time errors $(\mathrm{r}=0.888, \mathrm{p}<0.01)$. Thus, time errors are linked with the increase of uncertainty. Based on Tables 6, 8, and 10, this study introduces the relationships among uncertainty, time errors and delay in project management processes, as shown in the correlation model (Figure 4). 


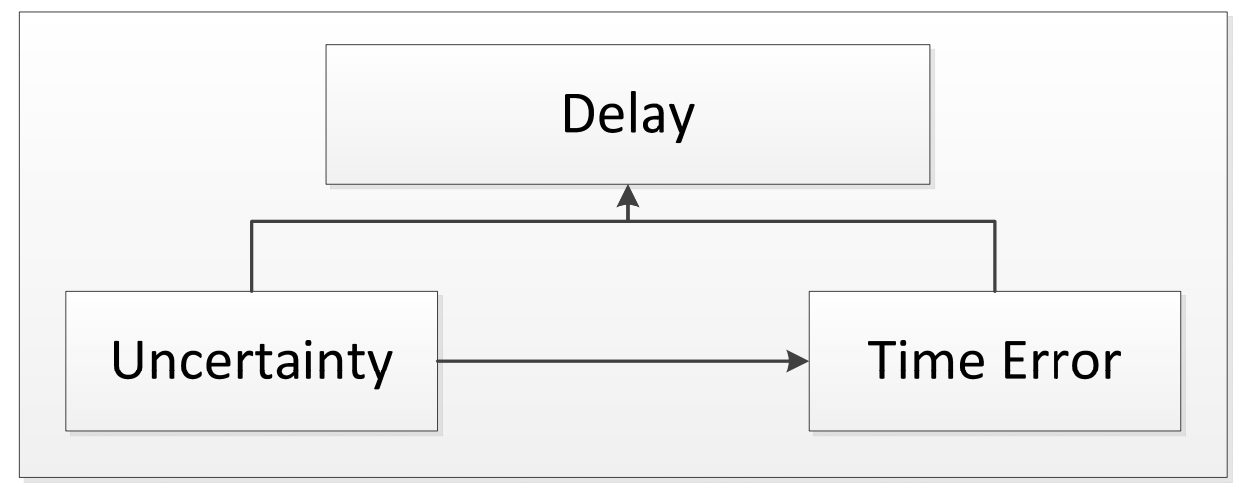

Figure 4. Correlation Model

The correlation model clarifies the relationships among the three variables. This paper argues that a project with more uncertainty and time errors is more likely to have delay problems. In addition, a project with more uncertainty is more likely to have time error problems. Therefore, uncertainty is the trigger of time error and delay occurrences. Moreover, delay can be a result of time errors. This contribution invites researchers and project management organizations to focus more on uncertainty. Although uncertainty is mentioned more than 40 times in the PMBOK guide, there is no specified knowledge area about uncertainty or uncertainty management. However, it is important to recognize that there are differences in the nature of risk and uncertainty, which are not mentioned in this paper.

Second, the findings show that time errors can occur in the 47 project management processes identified in the PMBOK guide. According to Table 12, this paper argues that there is a strong link between the high occurrence of time errors and the Monitoring and Controlling Process Group. The main reason behind this finding is that the previous process group includes controlling change requests, recommending corrective actions and preventing action potentials throughout the project lifecycle. Furthermore, this study argues that there is an association between the occurrence of time errors and the Planning Process Group because of updates arising from, for instance, approved changes or corrective and preventive actions, which may affect the project management plan.

\section{Conclusions}

Project delay continues to be a critical problem for organizations. This paper helps to determine when delay comes out in projects. No delay arises unless there are uncertainty and time errors. This paper is the first effort to explore the relationships among the three variables (uncertainty, time errors and delay). In addition, identifying where time errors can arise in the 47 project management processes identified in the PMBOK guide is a helpful contribution to the literature in the field of project management. This paper explores the relationships among uncertainty, time errors and delay. In addition, it explores where time errors can occur throughout project management processes. This paper claims that uncertainty is real and inventible in the project lifecycle. If uncertainty appears without being managed well, it will cause time errors and delay. This is based on the presence of time errors in the correlation model, so time errors that are not solved will lead to delay. It is important to note that time errors can be a negative (advance) or positive (delay) number, but delay is always a positive 
number in projects. Uncertainty is an incidence of the absence of data or information that leads to wrong decisions or indecision. This study provides new views concerning uncertainty and time errors in projects. Further research is required to obtain more insights and facts regarding uncertainty and time errors.

\section{References}

Altahtooh, U. A. (2016). Time Error in Project Management: A Case Study in Yanbu, Saudi Arabia. Business and Management Studies, 2(1), 58-64. http://dx.doi.org/10.11114/bms.v2i1.1277

Altahtooh, U. A., \& Emsley, M. W. (2015). IT Projects: Classifying Risk Factors and Identifying Project Outcomes. Journal of Industrial and Intelligent Information, 3(3), 246-252.

Altahtooh, U., \& Emsley, M. (2014). Is a Challenged Project One of the Final Outcomes for an IT Project? In System Sciences (HICSS), 47th Hawaii International Conference (pp. 4296-4304). IEEE. http://dx.doi.org/10.1109/hicss.2014.531

Anderson, S. D. (1992). Project Quality and Project Managers. International Journal of Project Management, 10(3), 138-144. http://dx.doi.org/10.1016/0263-7863(92)90002-Q

Harrington, H. J., Conner, D. R., \& Horney, N. L. (2000). Project Change Management: Applying Change Management to Improve Projects. New York: McGraw-Hill.

Hertz, D. B., \& Thomas, H. (1984). Risk Analysis and Its Applications. New York: John Wiley \& Sons.

Mayer, R. E. (1989). Models for Understanding. Review of Educational Research, 59(1), 43-64. http://dx.doi.org/10.3102/00346543059001043

Mertler, C. A., \& Vannatta, R. A. (2005). Advanced and Multivariate Statistical Methods: Practical Application and Interpretation (3rd edn.). Los Angeles, CA: Pyrczak.

Olsson, R. (2006). Managing Project Uncertainty by Using an Enhanced Risk Management Process. Doctoral Dissertation, Mälardalen University Press, Västerås, Sweden.

Pallant, J. (2010). SPSS Survival Manual: A Step-By-Step Guide to Data Analysis Using SPSS for Windows. Crows Nest: Australia, Allen and Unwin.

Project Management Institute (PMI). (2008). A Guide to the Project Management Body of Knowledge (3rd ed.) Newtown Square, PA: PMI.

Rowe, W. D. (1977). Anatomy of Risk. New York: John Wiley \& Sons.

Shi, J. J., Cheung, S. O., \& Arditi, D. (2001). Construction Delay Computation Method. Journal of Construction Engineering and Management, 127(1), 60-65. http://dx.doi.org/10.1061/(ASCE)0733-9364(2001)127:1(60)

Soldano, D., \& Krueger, L. (1994). Introduction to Project Management, Northcon/94 Conference Record.

Wateridge, J. (1997). Training for IS/IT project managers: A way forward. International $\begin{array}{llll}\text { Journal of Project } & \text { Management, } & 15(5),\end{array}$ http://dx.doi.org/10.1016/S0263-7863(96)00085-3 